\title{
The Efficacy of Subcutaneous Swabbing of Cesarean Section Wounds with Povidone Iodine to Prevent Post-Operative Wound Infection: A Randomized Controlled Study
}

\author{
DIAA EL-DEEN M. ABD EL-AAL, M.D.*; MOHAMMAD M.F. FATHALLA, M.D.*; \\ IBRAHEEM I. MOHAMMD, M.D.* and ASMAA M. ABD EL-NABY, M.Sc.**
}

The Department of Obstetrics and Gynecology, Faculty of Medicine, Assuit University* and Dairout General Hospital**

\begin{abstract}
Background: Cesarean delivery is one of the most common surgical procedures performed by obstetricians. Infectious morbidity after cesarean delivery can have a tremendous impact on the postpartum woman's return to normal function and her ability to care for her baby. Despite the widespread use of prophylactic antibiotics, post-operative infectious morbidity still complicates cesarean deliveries [1]. Wound irrigation with povidone-iodine, an antiseptic solution, may be useful for reducing infection, but it is of uncertain efficacy and risk. Povidone-iodine irrigation is a simple and inexpensive solution with the potential to prevent surgical site infection $\left[{ }^{2}\right]$.
\end{abstract}

Patients and Methods: This study was a randomized controlled prospective study in Assiut University Women's Health Hospital on women undergoing cesarean delivery in the period from November 2015 to September 2016. Study group (Group A) the subcutaneous tissue was swabbed with $10 \mathrm{cc}$ of undiluted $10 \%$ povidone iodine and was not mobbed. Group B; no swabbing.

Aim of Study: To assess the efficacy of subcutaneous swabbing of cesarean section wounds with povidone iodine to prevent post-operative wound infection.

Results: In our study, there was no statistically significant difference in personal and clinical history as regarding age, education, residence, urgency of cesarean section, presence of labor, gravidity, number of abortion but there was a statistical difference between the study groups in number of living children and number of previous cesarean section. There was no statistically significant difference in clinical examination as regarding BP, temperature, gestational age, presentation, presence of tender scar and rupture of membranes. There was a statistical difference between the study groups in pulse. There was a statistical difference between the study groups in investigations as regarding WBCs, estimated fetal weight and amniotic fluid index but there was a statistical difference in HB and platlets. There was no statistically significant difference in the operative data as regarding visceral and

Correspondence to: Dr. Diaa El-Deen M. Abd El-Aal, The Department of Obstetrics and Gynecology, Faculty of Medicine, Assuit University parietal peritoneal closure and duration of the procedure but there was a statistical difference in the level of the surgeon. There was no statistical difference between the study groups in presence of post-operative infection.

Conclusion: There was no benefit of subcutaneous tissue swabbing with povidone iodine in decreasing wound infection following cesarean section.

Key Words: Cesarean section - Wound infection - Povidone iodine.

\section{Introduction}

CESAREAN delivery defines the birth via the abdominal route [3]. From 1970 to 2010, the cesarean delivery rate in the United States rose from 4.5 percent of all deliveries to 32.8 percent [4]. In Egypt the rate of cesarean delivery is $51.8 \%$ of all deliveries [5].

Cesarean delivery is one of the most common surgical procedures performed by obstetricians. Infectious morbidity after cesarean delivery can have a tremendous impact on the postpartum woman's return to normal function and her ability to care for her baby. Despite the widespread use of prophylactic antibiotics, post-operative infectious morbidity still complicates cesarean deliveries [1]

Wound infection is an infrequent but serious complication of surgery. Post-operative infection often requires repeat surgery and prolonged hospitalization, and it may compromise ultimate surgical outcomes [6]

If prophylactic antimicrobials are given, the incidence of abdominal wound infection following cesarean delivery ranges from 2 to 10 percent depending on risk factors $[7,8]$ 
Numerous good quality trials have proved that a single dose of an antimicrobial agent given at the time of cesarean delivery significantly decreases infection morbidity [9]

Wound irrigation with povidone-iodine, an antiseptic solution, may be useful for reducing infection, but it is of uncertain efficacy and risk. Povidone-iodine irrigation is a simple and inexpensive solution with the potential to prevent surgical site infection [2].

Multiple studies investigated the use of povidone-iodine irrigation in multiple types of surgery. The infection rate was $2.9 \%$ in the treatment group and $15.1 \%$ in the control group ( $p<0.001)$. The treatment group did not experience any interference with wound healing or adverse reactions [2].

Povidone-iodine (Betadine) is an antiseptic solution consisting of polyvinylpyrrolidone with water, iodide and $1 \%$ available iodine; it has bactericidal ability against a large array of pathogens [10]. Although a vast amount of literature exists regarding its use as a topical antibacterical agent in surgery, its use as a prophylactic irrigation solution against surgical site infection has been examined to a lesser degree [2].

The aim of the study is to assess the efficacy of subcutaneous swabbing of cesarean section wounds with povidone iodine to prevent postoperative wound infection.

\section{Patients and Methods}

This study was conducted in Assiut University Women's Health Hospital including women undergoing cesarean delivery.

\section{Study design:}

Two armed randomized controlled clinical trial. The study has 2 groups. Group A in which the subcutaneous tissue will be swabbed with $10 \mathrm{cc}$ of undiluted $10 \%$ povidone iodine and will not be mobbed. Group B; no swabbing.

Inclusion criteria: All women who were admitted to labor ward either for elective or emergent; first time or repeat cesarean delivery.

Exclusion criteria: Women with prolonged rupture of membranes more than 12 hours, women with morbid obesity with BMI > 35, women with diabetes, hypertension or anemia with haemoglbin $<10$, women on corticosteroid therapy, women with intraoperative heamorrhage or hematoma formation, women allergic to betadine, the cesarean section which duration exceed one hour or associated with other surgical procedure.

\section{Patients enrollment:}

Ladies coming to emergency room or outpatient clinic for cesarean section were interviewed for feasibility to be enrolled in this study. The aim of the study and the procedure were explained to every woman in both verbal and written manner. Written or verbal consent was obtained according to patient education.

Pre-operative assessment: All patients underwent full history taking and clinical examination to ensure the diagnosis, indication of CS and to ensure that they comply with the inclusion and exclusion criteria.

\section{All participating women underwent the following:}

History taking regarding age, menstrual history, and obstetric history (gravidity, parity, nature of previous deliveries), general examination including weight, height, pulse, blood pressure, temperature, cardiac and chest examination to exclude any significant maternal disease, abdominal examination to detect fetal movement, scar of previous operations, fundal level, fetal lie and position, sterile speculum examination to diagnose rupture of membranes, complete blood picture, urine analysis and random blood sugar were done to all the patients.

Operative technique: Spinal anesthesia was utilized in all patients. Pre-operative single dose prophylactic antibiotics (Cefazolin 1g) were given to the patients on induction of anesthesia. Insertion of urinary catheter under complete aseptic conditions. Skin antisepsis with usual antiseptic solution (povidone iodine), draping with sterile covers. Opening skin by Pfannstiel incision, opening the anterior abdominal wall in layers, opening the uterus by sharp incision, delivery of the fetus, Spontaneous delivery of the placenta, closure of uterus in two layers, insuring homeostasis, closure of anterior abdominal wall in layers; the same type of suturing material; vicryl No1 was used in rectus Sheath, the subcutaneous tissue was closed, the same type of suturing material; vicryl NO $2 / 0$ was used in subcutaneous tissue and skin.

Group allocation: Before closure of the subcutaneous tissue the patients were randomized into two groups: Group A (study group); the subcutaneous tissue was swabbed with $10 \mathrm{cc}$ of undiluted 
$10 \%$ povidone iodine and was not mobbed and group B (control group); no swabbing was done.

Post-operative care and patient discharge: In the first hour after an uncomplicated cesarean section, the patient was monitored closely in the postpartum ward where urine output, pulse, blood pressure, respirations, and any evidence of bleeding can be closely observed. Once any nausea has abated, the patient was encouraged to take fluids orally and she can eat when she felt hungry. Early ambulation; getting the patient out of bed as soon as regional anesthesia had worn off was encouraged. The urinary catheter was removed 12 hours postoperatively unless this was be in the evening in which case it was removed in the following morning.

Wound care: The dressing was removed 24 hours after the caesarean section, specific monitoring for fever, the wound was assesed for signs of infection (such as increasing pain, redness, hotness, tenderness, oazing or discharge, separation or dehiscence), gentle cleaning and drying of the wound daily, the patients were discharged 24 hours post-operatively.

Patients follow-up: Patients were followed-up in the outpatient clinic while came to remove the stitches and a month later, patients who had their stitches removed outside the hospital were followed-up by telephone for symptoms of postoperative wound infection and were asked to come and meet the researcher if any suspension existed. Patients who had any signs of infection were seen daily until complete wound healing was obtained.

Outcome: The study outcome was to detect and record the incidence of surgical wound infection in both groups. It is a composite outcome with presence of any of the following was considered infection; induration, swelling of the wound edges, discharge of pus or wound dehiscence [11], purulent drainage with or without laboratory confirmation, from the superficial incision, pain or tenderness with redness, or heat, superficial incision being deliberately opened by surgeon [12]. The presence of infection means the presence of two or more of the following signs: (Fever, hotness, redness, tenderness, induration) or one or more of the following signs: (Swelling, ooze, discharge, dehiscence).

Sample size estimation: It was calculated that 299 patients are required in each arm to detect a $5 \%$ difference (from $2 \%$ to $7 \%$ ) in wound infection rate between study and control groups respectively using PS program.

\section{Statistical analysis:}

Data was collected, coded then, analyzed by computer software SPSS (statistical program for social science Version 16) as follows; numerical variables were expressed as mean or median whenever appropriate, categorical variables were presented as number of cases and percentage, Chisquare test was used to compare categorical variables between groups (fisher's exact if numbers in any column below 5), between groups comparison of contineous variables was performed by unpaired test (student's test) if they show normal distribution or ManWhitney test if they show non parametric distribution. Pearson correlation test was used for detection of correlation between variables, difference in variables was expressed by $p$-value $(>0.05$ is non significant, $<0.05$ is significant, and $<0.001$ is highly significant.

\section{Results}

This study included women undergoing cesarean delivery in the Women Health Hospital, Assuit University in the period from November 2015 to September 2016. There were 695 women eligible for the study 350 women in group A and 345 in group B. There were 51 women lost in follow-up either in first or second visit from group A and 46 women lost from group B. The net result was 598 women included in our analysis (299 in each group). There was no statistically significant difference in personal and clinical history as regarding age, education, residence, urgency of cesarean section, presence of labor, gravidity, number of abortion but there was a statistical difference between the study groups in number of living children and number of previous cesarean section. There was no statistically significant difference in clinical examination as regarding $\mathrm{BP}$, temperature, gestational age, presentation, presence of tender scar and rupture of membranes. There was a statistical difference between the study groups in pulse. There was a statistical difference between the study groups in investigations as regarding WBCs, estimated fetal weight and amniotic fluid index but there was a statistical difference in HB and platlets. There was no statistically significant difference in the operative data as regarding visceral and parietal peritoneal closure and duration of the procedure but there was a statistical difference in the level of the surgeon. There was no statistically significant difference between the study groups in presence of post-operative infection. 
There was a statistical difference in the level of the surgeon (as the infection rate was higher in cesarean sections done by specialists) and in women with rupture of membranes.

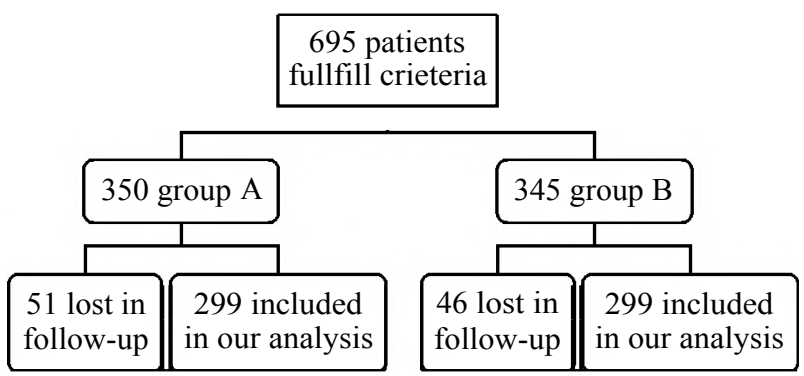

Fig. (1): Patient enrollment.

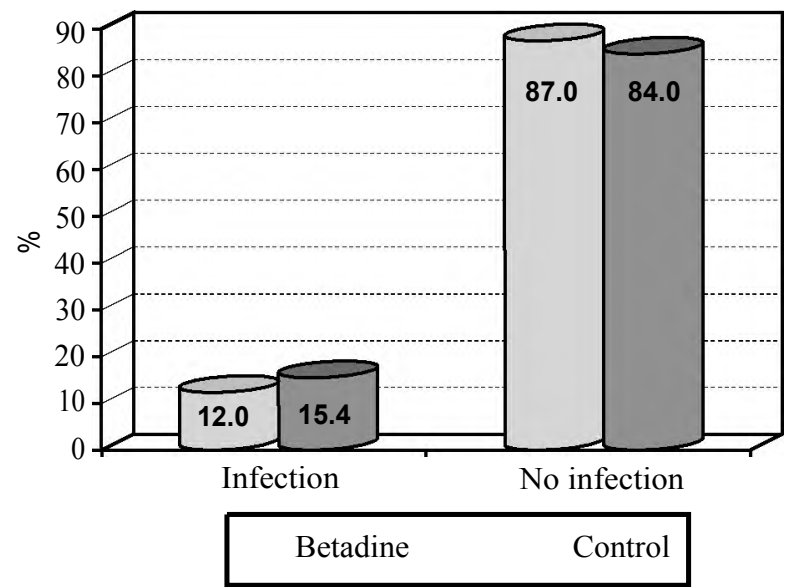

Fig. (2): The presence of either infection.

Table (1): Personal and clinical history.

\begin{tabular}{|c|c|c|c|c|c|}
\hline & \multicolumn{2}{|c|}{$\begin{array}{c}\text { Betadine } \\
(\mathrm{n}=299)\end{array}$} & \multicolumn{2}{|c|}{$\begin{array}{l}\text { Control } \\
(\mathrm{n}=299)\end{array}$} & \multirow{2}{*}{$\begin{array}{c}p- \\
\text { value }\end{array}$} \\
\hline & No. & $\%$ & No. & $\%$ & \\
\hline $\begin{array}{l}\text { Age: (years): } \\
\text { Mean } \pm \mathrm{SD} \\
\text { Range }\end{array}$ & \multicolumn{2}{|c|}{$\begin{array}{l}26.4 \pm 5.1 \\
15.0-40.0\end{array}$} & \multicolumn{2}{|c|}{$\begin{array}{l}26.4 \pm 4.6 \\
16.0-40.0\end{array}$} & 0.926 \\
\hline $\begin{array}{l}\text { Education: } \\
\text { No } \\
\text { Primary } \\
\text { Preparatory } \\
\text { Secondary } \\
\text { College }\end{array}$ & $\begin{array}{l}186 \\
11 \\
17 \\
78 \\
7\end{array}$ & $\begin{array}{l}62.2 \\
3.7 \\
5.7 \\
26 \\
2.3\end{array}$ & $\begin{array}{l}178 \\
12 \\
20 \\
84 \\
5\end{array}$ & $\begin{array}{l}59.5 \\
4 \\
6.7 \\
28 \\
1.7\end{array}$ & 0.907 \\
\hline $\begin{array}{l}\text { Residence: } \\
\text { Rural } \\
\text { Urban }\end{array}$ & $\begin{array}{l}204 \\
95\end{array}$ & $\begin{array}{l}68.2 \\
31.8\end{array}$ & $\begin{array}{l}191 \\
108\end{array}$ & $\begin{array}{l}63.9 \\
36.1\end{array}$ & 0.301 \\
\hline $\begin{array}{l}\text { Urgent or elective: } \\
\text { Elective } \\
\text { Urgent }\end{array}$ & $\begin{array}{l}218 \\
81\end{array}$ & $\begin{array}{l}72.9 \\
27\end{array}$ & $\begin{array}{l}220 \\
79\end{array}$ & $\begin{array}{l}73.6 \\
26.4\end{array}$ & 0.463 \\
\hline $\begin{array}{l}\text { Labour: } \\
\text { Not in labour } \\
\text { In labour }\end{array}$ & $\begin{array}{l}218 \\
81\end{array}$ & $\begin{array}{l}72.9 \\
27\end{array}$ & $\begin{array}{l}220 \\
79\end{array}$ & $\begin{array}{l}73.6 \\
26.4\end{array}$ & 0.463 \\
\hline Gravidity & \multicolumn{2}{|c|}{$2.93 \pm 1.8$} & \multicolumn{2}{|c|}{$2.96 \pm 1.7$} & 0.496 \\
\hline FTD & \multicolumn{2}{|c|}{$1.7 \pm 1.4$} & \multicolumn{2}{|c|}{$1.7 \pm 1.5$} & 0.912 \\
\hline No. of abortion & \multicolumn{2}{|c|}{$0.24 \pm 0.72$} & \multicolumn{2}{|c|}{$0.25 \pm 0.6$} & 0.323 \\
\hline No. of living children & \multicolumn{2}{|c|}{$1.66 \pm 1.46$} & \multicolumn{2}{|c|}{$1.69 \pm 1.5$} & $0.016^{*}$ \\
\hline No. of cesarean section & \multicolumn{2}{|l|}{$1 \pm 1$} & \multicolumn{2}{|c|}{$0.96 \pm 0.97$} & $0.047 *$ \\
\hline
\end{tabular}

Table (2): Examinations

\begin{tabular}{|c|c|c|c|}
\hline & $\begin{array}{c}\text { Betadine } \\
(\mathrm{n}=299)\end{array}$ & $\begin{array}{l}\text { Control } \\
(\mathrm{n}=299)\end{array}$ & $\begin{array}{c}p- \\
\text { value }\end{array}$ \\
\hline $\begin{array}{l}\text { Pulse: } \\
\quad \text { Mean } \pm \mathrm{SD} \\
\text { Range }\end{array}$ & $\begin{array}{l}86.20 \pm 4.4 \\
72.0-97.0\end{array}$ & $\begin{array}{l}85.5 \pm 4.6 \\
70.0-95.0\end{array}$ & $0.039^{*}$ \\
\hline $\begin{array}{l}\text { Systolic BP }(\mathrm{mm} \mathrm{Hg}) \text { : } \\
\text { Mean } \pm \mathrm{SD} \\
\text { Range }\end{array}$ & $\begin{array}{l}111.5 \pm 5.9 \\
100.0-130.0\end{array}$ & $\begin{array}{l}110.6 \pm 7.2 \\
100.0-130.0\end{array}$ & 0.110 \\
\hline $\begin{array}{l}\text { Diastolic BP }(m m ~ H g): \\
\quad \text { Mean } \pm \mathrm{SD} \\
\quad \text { Range }\end{array}$ & $\begin{array}{l}70.7 \pm 5.91 \\
60.0-80.0\end{array}$ & $\begin{array}{l}70.0 \pm 6.3 \\
60.0-80.0\end{array}$ & 0.142 \\
\hline $\begin{array}{l}\text { Temperature (c): } \\
\text { Mean } \pm \text { SD } \\
\text { Range }\end{array}$ & $\begin{array}{l}36.99 \pm 0.07 \\
36.0-37.2\end{array}$ & $\begin{array}{l}36.99 \pm 0.04 \\
36.6-37.0\end{array}$ & 0.501 \\
\hline $\begin{array}{l}\text { Gestational age (weeks): } \\
\text { Mean } \pm \mathrm{SD} \\
\text { Range }\end{array}$ & $\begin{array}{l}39.1 \pm 1.1 \\
38.0-40.0\end{array}$ & $\begin{array}{l}39.0 \pm 2.4 \\
37.0-40.0\end{array}$ & 0.496 \\
\hline $\begin{array}{l}\text { Presentation: No. (\%): } \\
\text { Cephalic } \\
\text { Breech }\end{array}$ & $\begin{array}{l}288(96.3 \%) \\
11 \quad(3.7 \%)\end{array}$ & $\begin{array}{ll}291 & (97.3 \%) \\
8 & (2.7 \%)\end{array}$ & 0.321 \\
\hline $\begin{array}{l}\text { Tender scar: No. }(\%) \text { : } \\
\text { Yes } \\
\text { No }\end{array}$ & $\begin{array}{l}32(10.7 \%) \\
267(89.3 \%)\end{array}$ & $\begin{array}{l}27(9 \%) \\
272(91.0 \%)\end{array}$ & 0.584 \\
\hline $\begin{array}{l}\text { Rupture of membranes: No. (\%): } \\
\text { Yes } \\
\text { No }\end{array}$ & $\begin{array}{ll}37 & (12.4 \%) \\
262 & (87.6 \%)\end{array}$ & $\begin{array}{ll}49 & (16.4 \%) \\
250 & (83.6 \%)\end{array}$ & 0.1 \\
\hline
\end{tabular}

Table (3): Investigations.

\begin{tabular}{llll}
\hline & Betadine $(\mathrm{n}=299)$ & Control $(\mathrm{n}=299)$ & $p$-value \\
\hline$H b(g m \%):$ & & & \\
$\quad$ Mean \pm SD & $11.72 \pm 0.56$ & $11.59 \pm 0.57$ & $0.006^{*}$ \\
$\quad$ Range & $10.3-13.0$ & $10.2-12.7$ & \\
WBCs: & & & \\
$\quad$ Mean $\pm \mathrm{SD}$ & $6.94 \pm 0.88$ & $6.87 \pm 0.81$ & 0.290 \\
$\quad$ Range & $4.2-11.7$ & $5.3-9.5$ & \\
PLT: & & & \\
$\quad$ Mean $\pm \mathrm{SD}$ & $262 \pm 51.167$ & $248 \pm 55.575$ & $0.002^{*}$ \\
$\quad$ Range & $158.4-450.0$ & $128.2-400.0$ & \\
EFW (kg): & & & \\
$\quad$ Mean $\pm \mathrm{SD}$ & $3.509 \pm 1.216$ & $3.536 \pm 0.720$ & 0.720 \\
$\quad$ Range & $2.3-4.4$ & $2.5-4.5$ & \\
AFI: $N o .(\%):$ & & & \\
$\quad$ Average & $223(74.6 \%)$ & $203(67.9 \%)$ & 0.336 \\
$\quad$ Decreased & $76(25.4 \%)$ & $96(32.1 \%)$ & \\
\hline
\end{tabular}

Table (4): Operative data.

\begin{tabular}{llllll}
\hline & \multicolumn{2}{c}{$\begin{array}{c}\text { Betadine } \\
(\mathrm{n}=299)\end{array}$} & \multicolumn{2}{c}{$\begin{array}{c}\text { Control } \\
(\mathrm{n}=299)\end{array}$} & $\begin{array}{c}p- \\
\text { value }\end{array}$ \\
\cline { 2 - 5 } & No. & $\%$ & No. & $\%$ & \\
\hline $\begin{array}{l}\text { Level of surgeon: } \\
\quad \text { Resident }\end{array}$ & 284 & 94.9 & 268 & 89.6 & $0.02 *$ \\
$\quad \begin{array}{l}\text { Specialist } \\
\text { Visceral perit closure: }\end{array}$ & 15 & 5.1 & 31 & 10.4 & \\
$\quad$ Yes & 287 & 95.9 & 282 & 94.3 & 0.389 \\
$\quad$ No & 12 & 4.1 & 17 & 5.7 & \\
$\begin{array}{l}\text { Parietal perit. closure: } \\
\quad \text { Yes }\end{array}$ & 290 & 97 & 284 & 95 & 0.348 \\
$\quad$ No & 9 & 3 & 15 & 5 & \\
$\begin{array}{l}\text { Duration: (min): } \\
\quad \text { Mean } \pm \text { SD }\end{array}$ & & & & & \\
$\quad$ Range & $33.59 \pm 5.57$ & $33.57 \pm 5.46$ & 0.969 \\
\hline
\end{tabular}


Table (5): First visit.

\begin{tabular}{|c|c|c|c|c|c|}
\hline & \multicolumn{2}{|c|}{$\begin{array}{l}\text { Betadine } \\
(\mathrm{n}=299)\end{array}$} & \multicolumn{2}{|c|}{$\begin{array}{l}\text { Control } \\
(\mathrm{n}=299)\end{array}$} & \multirow{2}{*}{$\begin{array}{c}p- \\
\text { value }\end{array}$} \\
\hline & No. & $\%$ & No. & $\%$ & \\
\hline \multicolumn{6}{|l|}{ Temperature (c): } \\
\hline Mean $\pm \mathrm{SD}$ & \multicolumn{2}{|c|}{$37.03 \pm 0.18$} & \multicolumn{2}{|c|}{$37.04 \pm 0.19$} & 0.588 \\
\hline Range & \multicolumn{2}{|c|}{$36.5-38.0$} & \multicolumn{2}{|c|}{$36.0-38.0$} & \\
\hline Redness & 16 & 5.4 & 21 & 7 & 0.249 \\
\hline Hotness & 13 & 4.3 & 18 & 6 & 0.461 \\
\hline Tenderness & 17 & 5.7 & 21 & 7 & 0.616 \\
\hline Induration & 12 & 4 & 14 & 4.7 & 0.842 \\
\hline Swelling & 9 & 3.0 & 14 & 4.7 & 0.396 \\
\hline Ooze of serous fluid & 23 & 7.7 & 38 & 12.7 & $0.028 *$ \\
\hline Discharge of pus & 8 & 2.7 & 8 & 2.7 & 1 \\
\hline Dehiscence & 7 & 2.3 & 4 & 1.3 & 0.545 \\
\hline Infection & 32 & 10.7 & 41 & 13.7 & 0.318 \\
\hline Fever $($ Temp >37.5) & 8 & 2.7 & 9 & 3.0 & 1 \\
\hline \multicolumn{6}{|l|}{ Infection score: } \\
\hline Mean \pm SD & \multicolumn{2}{|c|}{$0.51 \pm 1.6$} & \multicolumn{2}{|c|}{$0.67 \pm 1.8$} & \multirow[t]{2}{*}{0.254} \\
\hline Median (range) & \multicolumn{2}{|c|}{$0.0(0.0-11.0)$} & \multicolumn{2}{|c|}{$0.0(0.0-10.0)$} & \\
\hline \multicolumn{6}{|c|}{$\begin{array}{l}\text { - There was a statistically significant difference in the presence of } \\
\text { ooze. }\end{array}$} \\
\hline \multicolumn{6}{|c|}{ Table (6): Second visit. } \\
\hline & \multicolumn{2}{|c|}{$\begin{array}{l}\text { Betadine } \\
(\mathrm{n}=299)\end{array}$} & \multicolumn{2}{|c|}{$\begin{array}{l}\text { Control } \\
(\mathrm{n}=299)\end{array}$} & \multirow{2}{*}{$\begin{array}{c}p- \\
\text { value }\end{array}$} \\
\hline & No. & $\%$ & No. & $\%$ & \\
\hline \multicolumn{6}{|l|}{ Temperature: } \\
\hline Mean \pm SD & \multirow{2}{*}{\multicolumn{2}{|c|}{$\begin{array}{l}36.9 \pm 0.03 \\
36.5-37.0\end{array}$}} & \multirow{2}{*}{\multicolumn{2}{|c|}{$\begin{array}{l}37.00 \pm 0.01 \\
36.9-37.1\end{array}$}} & 0.194 \\
\hline Range & & & & & \\
\hline Redness & 0 & 0.0 & 3 & 1 & 0.249 \\
\hline Hotness & 0 & 0.0 & 1 & 0.3 & 0.5 \\
\hline Tenderness & 1 & 0.3 & 1 & 0.3 & - \\
\hline Induration & 0 & 0.0 & 1 & 0.3 & 0.5 \\
\hline Swelling & 0 & 0.0 & 1 & 0.3 & 0.5 \\
\hline Ooze & 3 & 1 & 5 & 1.7 & 0.505 \\
\hline Discharge & 3 & 1 & 3 & 1 & \\
\hline Dehiscence & 3 & 1 & 1 & 0.3 & 0.374 \\
\hline Infection & 2 & 0.7 & 5 & 1.7 & 0.287 \\
\hline Fever & 0 & 0.0 & 0 & 0.0 & - \\
\hline \multicolumn{6}{|l|}{ Infection score: } \\
\hline Mean \pm SD & \multicolumn{2}{|c|}{$0.064 \pm 0.63$} & \multicolumn{2}{|c|}{$0.084 \pm 0.75$} & 0.725 \\
\hline Median (range) & \multicolumn{2}{|c|}{$0.0(0.00-7.0)$} & \multicolumn{2}{|c|}{$0.0(0.00-11.00)$} & \\
\hline
\end{tabular}

There was no statistically significant difference.

Table (7): Presence of either first or second visit infection.

\begin{tabular}{lllllll}
\hline $\begin{array}{l}\text { Presence of } \\
\text { either infection }\end{array}$ & \multicolumn{2}{c}{$\begin{array}{c}\text { Betadine } \\
(\mathrm{n}=269)\end{array}$} & & \multicolumn{2}{c}{$\begin{array}{c}\text { Control } \\
(\mathrm{n}=269)\end{array}$} & $\begin{array}{c}p \text { - } \\
\text { value }\end{array}$ \\
\cline { 2 - 3 } & No. & $\%$ & & No. & $\%$ & \\
\hline Infection & 36 & 12.0 & & 46 & 15.4 & 0.285 \\
No infection & 263 & 87.0 & & 253 & 84.0 & \\
\hline
\end{tabular}

There was no statistically significant difference.
Table (8): Multiple logistic regression analysis.

\begin{tabular}{|c|c|c|c|c|}
\hline & \multirow{2}{*}{$p$-value } & \multirow{2}{*}{ OR } & \multicolumn{2}{|c|}{ 95\% C.I. } \\
\hline & & & Lower & Upper \\
\hline Level of surgeon (resident) & $0.014 *$ & 0.408 & 0.200 & 0.835 \\
\hline Rupture of membranes & $0.015^{*}$ & 2.059 & 1.153 & 3.678 \\
\hline Group (Betadine) & 0.426 & 1.214 & 0.753 & 1.957 \\
\hline Constant & 0.001 & 0.282 & & \\
\hline
\end{tabular}

\section{Discussion}

The study found an overall rate of CS wound infection of $13.7 \%$.

The overall incidence of post-operative infection in group A was $12 \%$ and $15.4 \%$ in group B but this difference was not statistically significant. The presence of rupture of membranes was associated with a significant increase in the risk of CS infection and surgery done by residents was associated with significantly less risk of infection.

\section{Study strengths and limitations:}

Random assignment and blinding of the patients to the assigned group is a point of strength. There was also a representative control group for evaluation. We used standard outcome measures by using the CDC definition of surgical site infection.

However, the investigator was not blinded to the assigned group as she had to do the majority of these surgeries. Due to financial restrictions, culture of wound could not be done.

In this study the overall rate of post cesarean infection was $13.7 \%$ which is consistent with a prospective cohort study for infection predictors where the overall rate of post cesarean infection was $12.4 \%$ [13] and another prospective study with an overall rate $13.9 \%[14]$.

However, post-cesarean infection rate was reported to vary from 1.1 to $25 \%$ in different studies, but comparison is difficult because of different populations, definitions, classifications and observation time $[\mathbf{8 , 1 5 - 2 0}]$.

Regarding level of surgeon, studies concluded that surgeons were responsible for their wound infection rates and the predisposition for succeeding wound infection was laid in the operating room [21].One study reported that registrars had significantly worse infection rates than consultant but also more infection rate than senior house officer [22].Another study found the overall infection rate for registrars and consultants operating on clinic patients, was double that for consultants operating on private patients [23]. This means that other 
factors may have contributed to the difference in CS infection risk. As this was not the main scope of research, we did not collect data on these factors e.g. number of personnel in the OR and surgical competence [24].

Although ROM was not prolonged in this study (not more than 12 hours) it was found to statistically significantly increase SSI after CS. Multiple studies found that presence of rupture of membranes is significantly associated with incidence of postcesarean infection [25-27]. Nielsen and Hökegård, 1982 found that duration of ruptured membranes prior to operation is significantly associated with incidence of infection ( $p$ less than 0.001) [13]. This means that rupture of membranes per se regardless of the duration can be a risk for CS infection. The presence of genital infection is a predisposing factor for rupture of membranes $[\mathbf{2 8 , 2 9 ]}$. These organisms may ascend after rupture of membranes to the uterus causing endometritis or wound infection.

The fact that povidone iodine use peroperative reduces CS infection was previously reported in general surgery in multiple systematic reviews $[2,30]$. They found povidone-iodine irrigation to be significantly more effective at preventing surgical site infection than the comparison interventions of saline, water or no irrigation. It is to be mentioned that they included clean, partially contaminated and contaminated surgeries.

The lack of a statistically significant difference between the two study groups in our study was reported by others [31,32]. In the first study, betadine applied after closure of the fascia was not statistically significantly higher than no irrigation but they included all women eligible for cesarean section unless they were allergic to betadine [31] In the second study, no difference between betadine and another antiseptic chlorhexidine in surgical site infection in elective cesarean section [32]. This means that the addition of povidone iodine before wound closure confers no added benefit in the reduction of surgical site infection following low infection risk cesarean section.

\section{Conclusion:}

There was no benefit of subcutaneous tissue swabbing with povidone iodine in decreasing wound infection following cesarean section.

\section{Recommendations:}

Recommendations for research: Auditing the implementation of interventions that reduce cesarean section rate, assessment of the operating room environment and compliance of different staff with infection control measures, assessment of surgical competence of the staff performing CS to evaluate the infection reducing measures, microbiological investigation of lower genital tract and intra amniotic spaces of women with recent rupture of membranes as the mere rupture of membranes was associated with increased risk of CS infection.

Recommendations for practice: The department must adopt interventions that reduce CS rate, training and refresher training of the operating room staff to infection control measures in operating room, regular assessment on the job of surgeons performance of essential procedures such as CS, patient with premature rupture of membranes should undergoe survillance for infection.

\section{References}

1- HAAS D.M., MORGAN S. and CONTRERAS K.: Vaginal preparation with antiseptic solution before cesarean section for preventing postoperative infections. Cochrane Database Syst. Rev., 1: CD007892, 2014.

2- CHUNDAMALA J. and WRIGHT J.G.: The efficacy and risks of using povidone-iodine irrigation to prevent surgical site infection: An evidence-based review, Canadian Journal of Surgery, Dec., 50 (6): 473-81, 2007.

3- BERGHELLA V.: Cesarean delivery in: Berghella V (editor): Obstetric Evidence Based Guidelines. $1^{\text {st }}$ Edition, Informa UK Ltd, Chapter 12: (91-8), 2007.

4- MARTIN J.A., HAMILTON B.E. and VENTURA S.J.: Births: Final data for 2010. Natl. Vital. Stat. Rep., 61 (1): 1, 2012.

5- Demographic and Health Survey 2014 (DHS), Egypt, Ministry of health and population, The DHS program, May 2015 p. 119. At dhs program.com/pubs/pdf/PR54/ PR54.pdf.

6- HEDRICK T.L., ANASTACIO M.M. and SAWYER R.G. Prevention of surgical site infections. Expert Rev. Anti. Infect. Ther., 4: 223-33, 2006.

7- ANDREW W.W., HAUTH J.C., CLIVER S.P., SAVAGE K. and GOLDENBERG R.L.:Randomized clinical trial of extended spectrum antibiotic prophylaxis with coverage for Ureaplasma urealyticum to reduce post-cesarean delivery endometritis. Obstet. Gynecol., June, 101 (6): 1183-9, 2003

8- CHAIM W., BASHIRI A., BAR-DAVID J., SHOHAMVARDI I. and MAZOR M.: Prevalence and clinical significance of postpartum endometritis and wound infection. Infect Dis. Obstet. Gynecol., 8 (2): 77-82, 2000.

9- American College of Obstetricians and Gynecologists. Prophylactic antibiotics in labor and delivery. Practice Bulletin No. 120, June 2011.

10-ZAMORA J.L.: Chemical and microbiologic characteristics and toxicity of povidone-iodine solutions. Am. J. Surg., 151: 400-6, 1986.

11- ABDEL BADEE A.Y., ALI M.K., ABBAS A.M. and SHAZLY S.A.M.: Evaluation of povidone Iodine $10 \%$ 
versus $7.5 \%$ hand scrub in cesarean section wound infections: A prospective Trial, International Journal of Obstetrics and Gynecology, Vol. 2 (3), pp. 045-051, March, 2014.

12- HORAN T.C., GAYNES R.P., MARTONE W.J., JARVIS W.R. and EMORI T.G.: "CDC definitions of nosocomial surgical site infections, 1992: A modification of CDC definitions of surgical wound infections," Infection Control and Hospital, Epidemiology, Vol. 13, No. 10, pp. 606-8, 1992.

13-TRAN T.S., JAMULITRAT S., CHONGSUVIVATWONG V. and GEATER A.: Risk factors for postcesarean surgical site infection. Obstetrics \& Gynecology, 95 (3): 367-71, 2000.

14- NIELSEN T.F. and HOKEGARD K.H.: Post-operative cesarean section morbidity: A prospective study. Am. J. Obstet. Gynecol., 146: 911-5, 1982.

15- EHRENKRANZ N., BLACWELDER W., PFAFF S. POPPE D., YERG D. and KASLOW R.: Infections complicating low-risk cesarean sections in community hospitals: Efficacy of antimicrobial prophylaxis. Am. J. Obstet. Gynecol., 162:337-43, 1990.

16- MITT P., LANG K., PERI A. and MAIMETS M.: Surgicalsite infections following cesarean section in an Estonian university hospital: Postdischarge surveillance and analysis of risk factors. Infect. Control Hosp. Epidemiol., 26: 44954, 2005.

17- BARWOLFF S., SOHR D., GEFFERS C., BRANDT C., VONBERG R.P., HALLE H., et al.: Reduction of surgical site infections after caesarean delivery using surveillance. J. Hosp. Infect., 63 (2): 156-61, 2006.

18- COUTO R., PEDROSA T., NOGUEIRA J., GOMES D., NETO M. and REZENDE N.: Post-discharge surveillance and infection rates in obstetric patients. Int. J. Gynaecol. Obstet., 61 (3): 227-31, 1998

19- BARBUT F., CARBONNE B., TRUCHOT F., SPIELVOGEL C., JANNET D., GODEREL I., et al.: Surgical site infections after cesarean section: Results of a five-year prospective surveillance. J. Gynecol. Obstet. Biol. Reprod, 33 (6 Pt 1): 487-92, 2004.

20- CREEDY D. and NOY D.: Post-discharge surveillance after cesarean section. Birth, 28 (4): 264-9, 2001

21- CRUSE P.J.E. and FOORD R.: The edpidemiology of wound infection. A 10-year prospective study of 62,939 wounds. The Surgical Clinics of North America, 60: 2740, 1980.

22- MOIR-BUSSY R.M., HUTTON R.M. and THOMPSON J.R.: Wound infection after caesarean section. Journal of Hospital Infection, 5: 359-70, 1984.
23- WEBSTER J.: Post-caesarean wound infection: A review of the risk factors. The Australian \& New Zealand Journal of Obstetrics \& Gynaecology, 28: 201-7, 1988.

24- DAVIDSON A.I.G., CLARK C. and SMITH G.: Postoperative wound infection: A computer analysis. The British Journal of Surgery, 58: 333-7, 1971.

25- SHEINER E., SHOHAM-VARDI I., WEITZMAN D., GOHAR J. and CARMI R.: Decisions regarding pregnancy termination among Bedouin couples referred to third level ultrasound clinic. Eropean Journal of Obstetrics, Gynecology and Reproductive Biology, 76: 141-6, 1988.

26- KILLIAN C.A., GRAFFUNDER E.M., VINCIGUERRA T.J. and VENEZIA R.A.: Risk factors for surgical-site infections following cesarean section. Infection Control And Hospital Epidemiology, 22 (10): 613-7, 2001.

27- SHRESTHA S., SHRESTHA R., SHRESTHA B. and DONGOL A.: Incidence and risk factors of surgical site infection following cesarean section at Dhulikhel Hospital. Kathmandu. Univ. Med. J. (KUMJ), Apr.-Jan., (46): 1136, 2014 .

28- CASSELL G.H., DAVIS R.O., WAITES K.B., et al.: Isolation of Mycoplasma hominis and Ureaplasma urealyticum from amniotic fluid at 16-20 weeks of gestation: potential effect on outcome of pregnancy. Sex Transm. Dis., 10: 294-302, 1983.

29- GRAY D.J., ROBINSON H.B., MALONE J. and THOMSON R.B., Jr.: Adverse outcome in pregnancy following amniotic fluid isolation of Ureaplasma urealyticum. Prenat. Diagn., 12: 111-7, 1992.

30- TARA C. MUELLER, MARTIN LOOS, BERNHARD HALLER, ANDRÉ L. MIHALJEVIC, ULRICH NITSCHE, DIRK WILHELM, HELMUT FRIESS, JÖRG KLEEFF, FRANZ G. and BADER.: Intra-operative wound irrigation to reduce surgical site infections after abdominal surgery: A systematic review and meta-analysis. Langenbeck's Archives of Surgery. February, Volume 400, Issue 2, pp. 167-81, 2015.

31- KASSAM M., IBINABO I. and JULIE B.: The Betadine trial-antiseptic wound irrigation prior to skin closure at cesarean section to prevent surgical site infection: Arandomised controlled trial. Australian and New Zealand Journal of Obstetrics and Gynaecology, 56: 301-6, 2016.

32- AWORINDE O., AWORINDE K.O., FEHINTOLA A., ADEYEMI B., OWONIKOKO M. and ADEYEMI A.S. Antiseptic Skin Preparation for Preventing Surgical Site Infection at Caesarean Section. Open Journal of Obstetrics and Gynecology, 6, 246-51. Published Online March 2016 in Sci. Res. http://www.scirp.org/journal/ojog . http://. dx.doi.org/10.4236/ojog.2016.64031, 2016. 


\section{فعالية مسح آنسجة تحت الجلد بمحلول بوفيدون اليون اليود

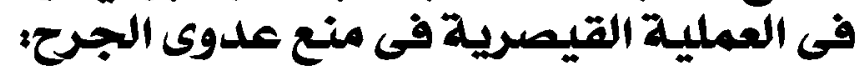 دراسة عشوائية منضبطة مليطة}

تقييم فعالية مسح تحت الجلد فى الجروح القيصرية بإستخدام بوفيدف اليود اللوقاية من علوى الجرح بعد العملية الجراحية.

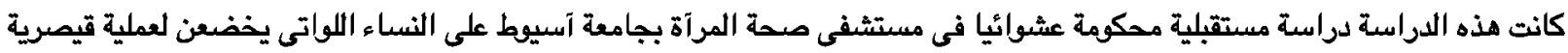

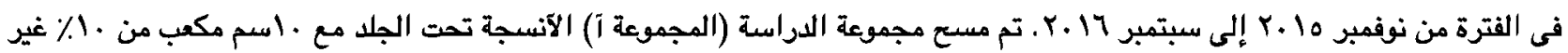
مخفف اليود بوفيدون ولم تتم إزالته. المجموعة باء، لم يتم إستخدامه.

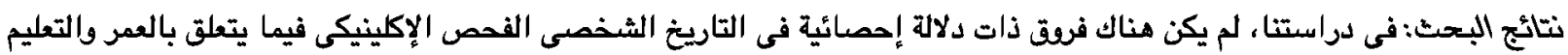

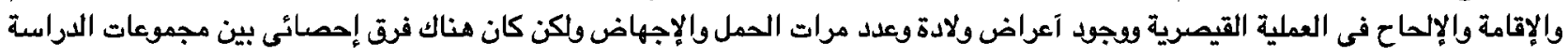

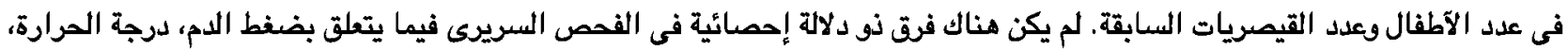

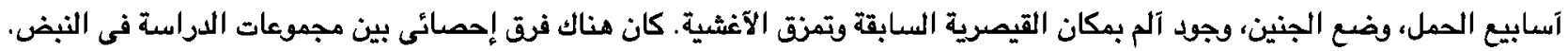

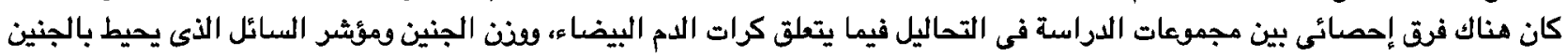

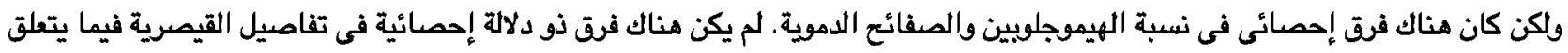

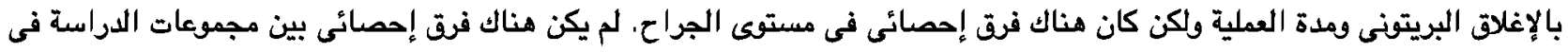

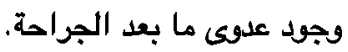

الخلاصة: لم يكن هناك فائدة من مسع الآنسجة تحت الجلد بإستخدام بوفيدف اليود فى خفض عدوى الجرح بعد العملية القيصرية. 